\title{
Identification of Preferential Runoff Belts in Jinan Spring Basin Based on Hydrological Time-Series Correlation
}

\author{
Shuyao Niu ${ }^{1,2}$, Longcang Shu ${ }^{1,2, *}, \mathrm{Hu} \mathrm{Li}^{3}$, Hua Xiang ${ }^{4}$, Xin Wang ${ }^{3}$, Portia Annabelle Opoku ${ }^{1,2}$ and Yuxi Li ${ }^{1,2}$ \\ 1 State Key Laboratory of Hydrology-Water Resources and Hydraulic Engineering, Hohai University, \\ Nanjing 210098, China; n1148603335@163.com (S.N.); portiafaith2015@gmail.com (P.A.O.); \\ 15044030896@163.com (Y.L.) \\ 2 College of Hydrology and Water Resources, Hohai University, Nanjing 210098, China \\ 3 Jinan Rail Transit Group Co., Ltd., Jinan 250101, China; lihu1007@163.com (H.L.); \\ wangxin2014hhu@163.com (X.W.) \\ 4 Hydrology Center of Shandong, Jinan 250002, China; xianghua_sdsw@shandong.cn \\ * Correspondence: lcshu@hhu.edu.cn; Tel.: +86-138-5194-1641
}

check for updates

Citation: Niu, S.; Shu, L.; Li, H.; Xiang, H.; Wang, X.; Opoku, P.A.; Li, Y. Identification of Preferential Runoff Belts in Jinan Spring Basin Based on Hydrological Time-Series Correlation. Water 2021, 13, 3255. https://doi. org/10.3390/w13223255

Academic Editor: Lahcen Zouhri

Received: 9 August 2021

Accepted: 15 November 2021

Published: 17 November 2021

Publisher's Note: MDPI stays neutral with regard to jurisdictional claims in published maps and institutional affiliations.

Copyright: (c) 2021 by the authors. Licensee MDPI, Basel, Switzerland. This article is an open access article distributed under the terms and conditions of the Creative Commons Attribution (CC BY) license (https:// creativecommons.org/licenses/by/ $4.0 /)$.

\begin{abstract}
The Jinan karst system is one of the typical karst systems in North China. The karst springs in Jinan are important historical heritage in China. However, in recent years, due to urbanization and the excessive exploitation of groundwater resources in Jinan City, the rate of spring flow has decreased tremendously. Preferential runoff belts are channels of karst aquifers where fractures and conduits are well-developed and serve as the main pathways for groundwater movement and solute transport. In view of this, a study was conducted in the Jinan Spring Basin to identify preferential runoff belts based on hydrological time-series correlation. Firstly, through cross wavelet transform and Pearson correlation coefficient, the time-lag and correlation of spring water level and precipitation were analyzed, the result show that the precipitation in the areas of Xinglong, Donghongmiao, Qiujiazhuang, Xiying, Yanzishan and Liubu stations has a greater impact on spring water level. In addition, combined with the hydrogeological conditions of the Jinan Spring Basin, the above stations meet the characteristics of the preferential runoff belt. In conclusion, the above stations are most likely to be located on the preferential runoff belt. The results of this study can serve as great reference points for building a correct hydrogeological conceptual model, and for the future planning of spring protection measures.
\end{abstract}

Keywords: Jinan Spring Basin; preferential runoff belt; hydrological time-series analysis; wavelet analysis; time-lag; correlation coefficient

\section{Introduction}

More than $25 \%$ of the world's population either lives on or obtains water from karst aquifers, which makes the understanding of these systems crucial to water management [1]. The Jinan karst system is one of the typical karst systems in North China, and karst aquifers contain much of the groundwater resource, which is an important water source. The Cambrian and Ordovician carbonate rocks, which are easily dissolvable, are widely distributed in Jinan. Affected by geological structure, lithology, climate and other factors, a large number of karst fractures and pipelines have been developed, which have become a good channel for groundwater migration and a huge storage space. Jinan City has been known as "Spring City" since ancient times because of its fractured-karst springs. Spring is a concentrated discharge of groundwater appearing at the ground surface as a current of flowing water. However, in recent years, due to social and economic development in Jinan, urbanization has significantly accelerated the extraction of karst groundwater. Despite the fact that protective measures such as limited exploitation and artificial recharge of groundwater have been adopted in Jinan, the spring is still at risk of drying up. This is mainly because of insufficient understanding about the spring recharge [2-4]. It is 
extremely important to carry out karst water protection scientifically and effectively in the Jinan Spring Basin. Artificial recharge has a dependable repair effect on Jinan karst water systems [5,6]. Jinan springs are mainly affected by natural factors and human factors. Natural factors include atmospheric precipitation, and human factors include groundwater exploitation and urbanization [3,7]. The primary factor that has affected spring dynamics since 2003 is atmospheric precipitation [5]. Precipitation infiltration is a major recharge source of karst groundwater in karst region, and the variation of groundwater level and spring discharge in Jinan is closely related to precipitation [8]. Using remote sensing technology and groundwater numerical simulation, it was found that rapid urbanization has reduced precipitation infiltration recharge in the Jinan Spring Basin [9]. The time-lag of spring water level and precipitation in Jinan on a yearly scale for 1959-2011 is around 3-4 months based on wavelet transform [10]. Precipitation and spring discharge data are considered the input and output signals of a karst spring catchment, respectively [11]. Karst aquifers have very high spatial heterogeneity, the distributions of pores, fractures, and conduits in karst aquifers are extremely uneven, and this heterogeneity strongly influences the hydraulic behavior of the karst. From the south of the Jinan Spring Basin to the spring discharge area, the karst development varies from weak to strong, forming a complex underground network system of dissolution fissures-caves-pipes. The higher the degree of karst development, the better the permeability. The karst near the spring is the most developed, where dissolution conduits and fractures form a strong karst development zone. According to the analysis of existing borehole data in the Jinan Spring Basin, the hydraulic conductivity is $10-100 \mathrm{~m} / \mathrm{d}$ in most areas, and may be greater than $100 \mathrm{~m} / \mathrm{d}$ in the area near the spring.

Preferential runoff belts are channels of karst aquifers where fractures and conduits are well-developed and serve as the main pathways for groundwater movement and solute transport [12-14]. Preferential runoff belts control most of the hydrological response of the aquifer [11], and cause the karst groundwater to quickly reach the spring, so it is more effective to recharge the spring on preferential runoff belts. In addition, the identification of these runoff belts is critical for building the correct hydrogeological conceptual model, and for future planning of spring protection measures. The characteristics of karst channels was studied through tracer tests and spring water level dynamic observations in the Jinan Spring Basin $[3,15,16]$, and the results show that the karst water runoff channel has single-pipeline and multiple-pipelines in the Jinan Spring Basin; the development of runoff channels is controlled by permeable fractures, and there is a preferential runoff belt through the northern of the Qianfoshan Fault. There are few studies on identifying preferential runoff belt by mathematical methods in the Jinan Spring Basin. The traditional method to find preferential runoff belt is analyzing a considerable amount of hydrogeological data, such as hydrogeological map, hydrogeological profile, groundwater data (e.g., water levels, hydraulic conductivity, flow rates, and others) and so on. In addition, groundwater data are sparse in most karst terranes, so it is generally difficult to characterize the spatial distribution of preferential runoff belts in karst aquifer $[17,18]$. The geological structure of the Jinan Spring Basin is rather complex; therefore, accurate characterization of its hydrogeological characteristics requires a lot of data. many researchers have conducted investigations in the Jinan Spring Basin. However, hydrogeological exploration and hydrogeological mapping are expensive and time consuming. Moreover, it is difficult to carry out detailed field geological surveys in the entire spring basin, and the information currently obtained is not enough to describe the spring basin very finely. The cost of obtaining hydrological time-series data is low and time-saving. Using hydrological time-series to identify the most likely location of preferential runoff belt can carry out hydrogeological survey more pertinently, which can preliminarily locate the preferential sites of recharge and exploitation. The purpose of the project described in this paper is to identify preferential runoff belts in the Jinan Spring Basin by analyzing hydrological time-series correlation.

Wavelet analysis as a mathematical method has developed rapidly in recent years and is widely used in image processing and time-series analysis. Wavelet analysis is a data pro- 
cessing and analysis method that has been found to be effective for hydrologic time-series analysis and can facilitate the analysis of multitemporal-scale structures, identification of deterministic components, noise removal, and quantification of complexity [19-23]. Furthermore, the Continuous Wavelet Transform (CWT) can reveal the cross-correlation and coherence of hydrologic time-series [24,25]. The Cross Wavelet Transform (XWT) is built on two CWTs to disclose their common power and relative phase in time-frequency space [24]. The XWT can examine relationships in time frequency space between two time-series, and can calculate cross wavelet phase angle, the cross wavelet phase angle can be used to analyze the time-lag of two time-series [24]. For example, the XWT was utilized to investigate the correlation between groundwater level, spring water level or spring flow and precipitation, and quantify the lag characteristics of water level or flow dynamic response to precipitation [25-28]. Correlation has also gained popularity in hydrological research, with correlation being used to study precipitation [29], evapotranspiration [30], surface water [31], and groundwater [25]. Pearson correlation coefficient is one of the most commonly utilized correlation coefficients for determining the linear correlation between two variables [32].

The goal of this paper is to apply XWT and the Pearson correlation coefficient to analyze the relationship between spring water level and precipitation in the Jinan Spring Basin. Cross wavelet transform was used to calculate the time-lag of the spring water level and the precipitation, and the Pearson correlation coefficient of spring water level and precipitation was calculated. According to the groundwater level data of the Jinan Spring Basin, phreatic water is mainly distributed in the northwest of the Jinan Spring Basin, and the aquifer is mainly Quaternary, moreover, only some small areas in the northwest of the Jinan Spring Basin have groundwater depths of $0-5 \mathrm{~m}$, the buried depth in most areas is greater than $5 \mathrm{~m}$, and the phreatic evaporation is very small [33], so in this study, evaporation is not considered. In addition, the analysis result of spring water level and precipitation was compared with the groundwater level in different places and precipitation. Precipitation signals can quickly reach the aquifer and impact groundwater levels in locations with a high karst development degree. Therefore, the time-lag between the two is short and the correlation coefficient is high. On the contrary, in areas with a low degree of karst development, the time-lag is long and the correlation coefficient between the two is relatively small $[11,27]$. Finally, the result of the XWT and Pearson correlation coefficient was combined with the hydrogeological conditions of the study area to determine whether the precipitation station is located in the preferential runoff belts.

\section{Study Area}

The Jinan Spring Basin is located in midwestern Shandong Province, with Mountain Tai to the south and the Yellow River Plain to the north; because of this landscape, the elevation reduces from south to north [2,34-36]. The southern boundary of the Jinan Spring Basin is the surface divide of Mountain Tai, the northern boundary is the CarboniferousPermian igneous rocks, and the east and west are, respectively, bounded by the Dongwu Fault and the Mashan Fault (Figure 1). The annual average precipitation of the Jinan Spring Basin is approximately $650 \mathrm{~mm}$ [2], the spatial distribution of precipitation is uneven, and the overall distribution trend decreases from southeast to northwest.

Jinan has many springs because of its unique topographic features and geological structure. The Jinan karst aquifer system has a gentle monoclinic structure, with limestone serving as the main aquifer in the groundwater system. Limestone is easily dissolvable, forming a complex underground network system of dissolution fissures-cavities-pipes in Jinan. Karst groundwater flows mainly from south to north, which corresponds to the karst strata's dipping and the topography $[5,35]$. In the southern part of the Jinan Spring Basin, the basement of the aquifer is consisting of Archean Taishan Group. The basement in the middle of the Jinan Spring Basin is covered by Cambrian and Ordovician karst carbonate rock strata (Figure 1), and the Cambrian is characterized by the interbeds of limestone and shale. While the Ordovician is composed of thick limestone, argillaceous limestone 
and dolomitic limestone, with developed karst fissures and strong permeability, which are conducive to groundwater recharge, runoff and discharge. The consistency of topography and limestone occurrence causes the karst water to be recharged by atmospheric precipitation controlled by topography and karst network system flowing from south to north (Figure 2). In the north of the Jinan Spring Basin, karst groundwater flow is obstructed by impermeable Mesozoic igneous rocks or Carboniferous-Permian sand and shale, and collects in the contact zone. Under the influence of high water pressure, the confined karst groundwater flows out as ascending springs in the suitable topographic and structural areas (Figure 2) [37]. Amongst many springs in Jinan, the Baotu Spring (BTS) and the Heihu Spring (HHS) are the most well-known. However, due to the over-exploitation of the karst groundwater and changes in the recharge conditions, the discharge from the springs has been declining continuously in recent years, and the springs have dried up during dry seasons [2,37]. Therefore, BTS and HHS are selected as the representative springs in this study.

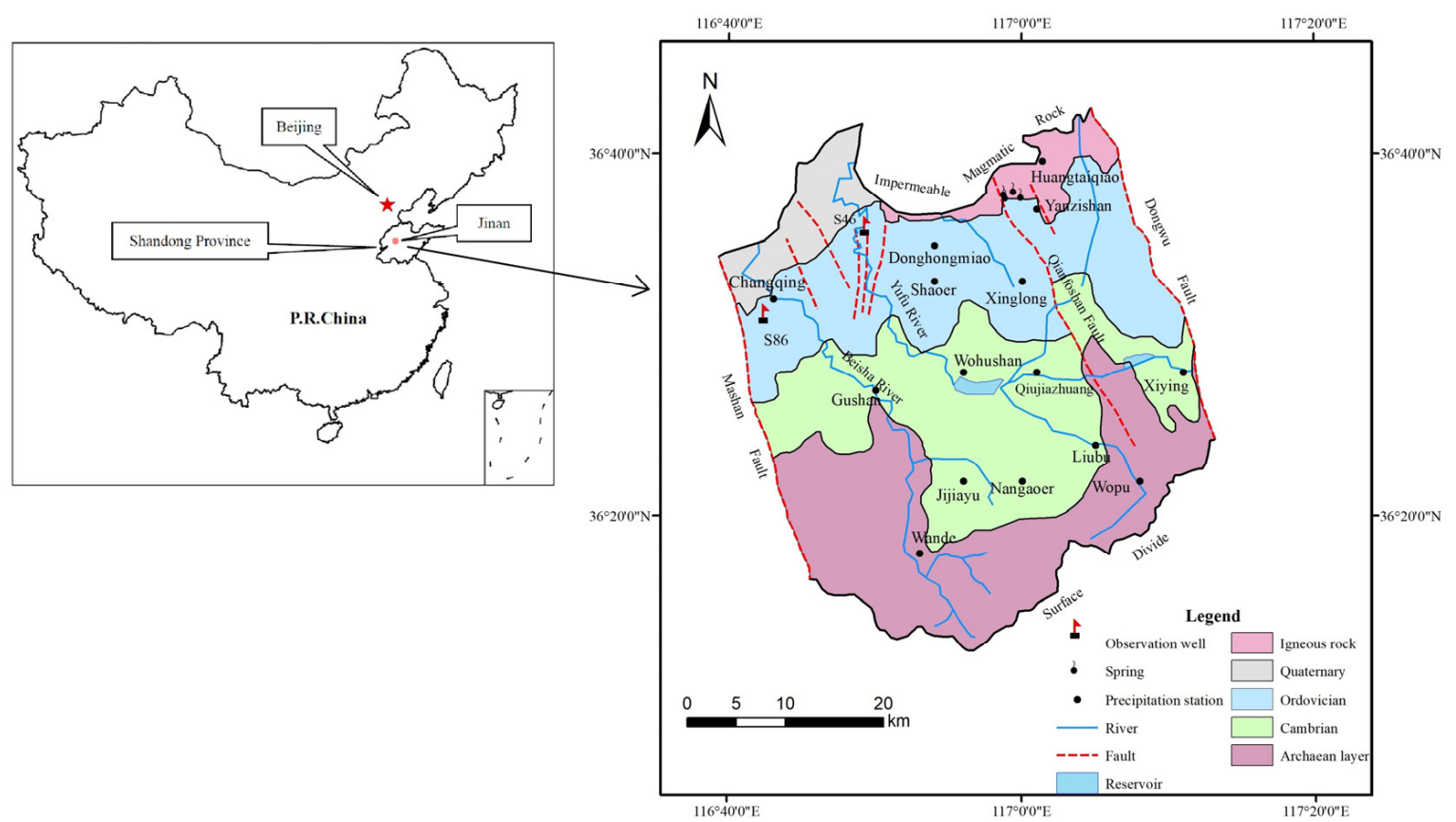

Figure 1. Distribution of precipitation stations in Jinan Spring Basin.

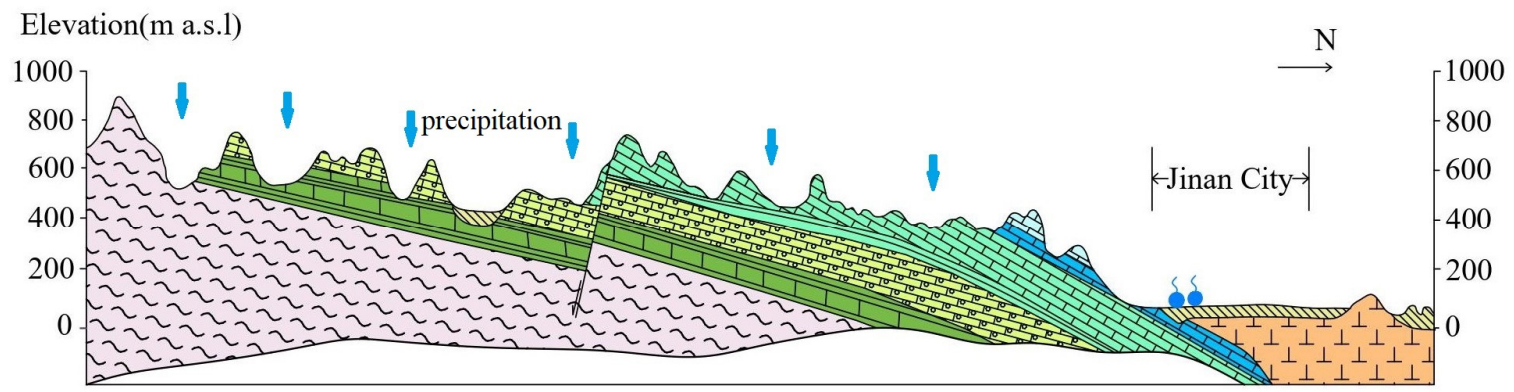

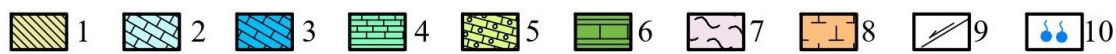

Figure 2. Hydrogeological cross-section of Jinan Spring Basin (south-north). 1 Soil $\left(\mathrm{Q}_{4}\right), 2$ Limestone $\left(\mathrm{O}_{2}\right), 3$ Dolomitic limestone $\left(\mathrm{O}_{1}\right), 4$ Limestone and shale $\left(\epsilon_{3}\right), 5$ Oolitic limestone $\left(\epsilon_{3}\right), 6$ Limestone and shale $\left(\in_{3}\right), 7$ Granitic gneiss $\left(\right.$ Ar $\left._{3}\right)$, 8 Diorite (Mz), 9 Fault, 10 Springs. 


\section{Data and Methods}

\subsection{Data}

The data used include the precipitation, spring water and groundwater level records in the Jinan Spring Basin. The observed daily precipitation time-series from January 2010 to December 2019 were collected from fifteen precipitation stations in the Jinan Spring Basin. The daily BTS and HHS water level time-series from January 2010 to December 2019 were obtained from Jinan Urban and Rural Water Affairs Bureau website (http: / /jnwater.jinan.gov.cn (accessed on 30 June 2020)), precipitation and spring water level time-series are both from January 2010 to December 2019. Groundwater level is obtained from observation well S46 and S86, is also daily record from January 2010 to December 2017. The location of each precipitation station and observation wells in the Jinan Spring Basin is shown in Figure 1, and the basic information of each precipitation station is shown in Table 1. The monthly average precipitation of the study area, spring water level and groundwater level time-series are shown in Figure 3.

Table 1. Basic information of each precipitation station.

\begin{tabular}{cccccc}
\hline Station & $\begin{array}{c}\text { Annual Average } \\
\text { Precipitation/mm }\end{array}$ & $\begin{array}{c}\text { Distance to } \\
\text { BTS/km }\end{array}$ & $\begin{array}{c}\text { Distance to } \\
\text { HHS/km }\end{array}$ & $\begin{array}{c}\text { Distance to } \\
\text { S46/km }\end{array}$ & $\begin{array}{c}\text { Distance to } \\
\text { S86/km }\end{array}$ \\
\hline Changqing & 663.70 & 25.75 & 27.24 & 13.69 & 2.42 \\
Huangtaiqiao & 639.10 & 5.52 & 4.69 & 19.58 & 3.83 \\
Donghongmiao & 515.90 & 8.63 & 10.03 & 7.27 & 19.11 \\
Shaoer & 640.42 & 11.11 & 12.26 & 8.71 & 17.95 \\
Xinglong & 572.95 & 8.66 & 8.57 & 16.85 & 26.74 \\
Yanzishan & 538.10 & 3.43 & 2.04 & 17.75 & 30.16 \\
Gushan & 692.29 & 23.59 & 24.57 & 16.11 & 13.54 \\
Qiujiazhuang & 527.85 & 18.02 & 17.89 & 22.62 & 28.43 \\
Wohushan & 677.11 & 18.22 & 18.73 & 17.46 & 21.15 \\
Xiying & 555.90 & 25.41 & 24.36 & 35.49 & 43.19 \\
Jijiayu & 569.40 & 29.13 & 29.48 & 27.27 & 26.21 \\
Liubu & 549.90 & 26.77 & 26.34 & 31.98 & 36.21 \\
Nangaoer & 749.36 & 28.88 & 28.91 & 30.00 & 31.10 \\
Wopu & 731.62 & 31.92 & 31.35 & 37.78 & 41.74 \\
Wande & 626.19 & 37.25 & 37.73 & 33.19 & 28.63 \\
\hline
\end{tabular}

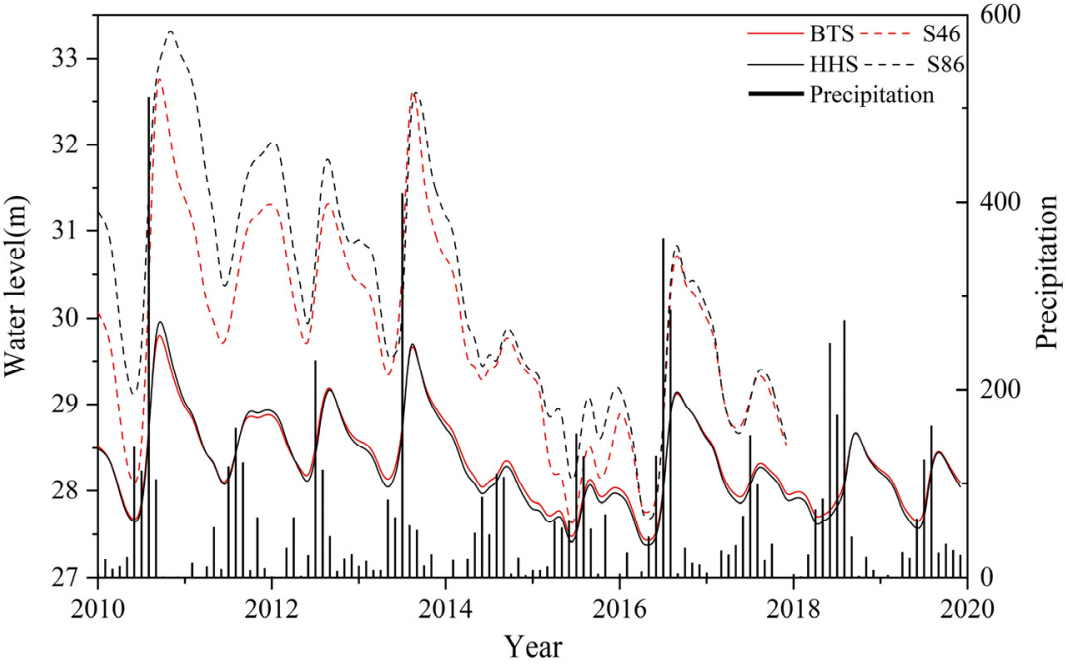

Figure 3. Plots of monthly precipitation, spring water level and groundwater level.

\subsection{The Continuous Wavelet Transform (CWT)}

The idea behind the CWT is to apply the wavelet as a bandpass filter to the time series. The wavelet is stretched in time by varying its scale $(s)$, the CWT of a time series $\left(x_{n}, n=1\right.$, 
$\ldots, N)$ with uniform time steps $\delta_{t}$, is defined as the convolution of $x_{n}$ with the scaled and normalized wavelet:

$$
W_{n}^{X}(s)=\sqrt{\frac{\delta_{t}}{s}} \sum_{n^{\prime}=1}^{N} x_{n^{\prime}} \psi_{0}\left[\left(n^{\prime}-n\right) \frac{\delta t}{s}\right]
$$

where $\psi_{0}$ is the Morlet wavelet. The Morlet wavelet is defined as:

$$
\psi_{0}(\eta)=\pi^{-\frac{1}{4}} e^{i w_{0} \eta} e^{-\frac{1}{2} \eta^{2}}
$$

where $\omega_{0}$ is dimensionless frequency and $\eta$ is dimensionless time, $\eta=s \cdot t$.

The wavelet power is defined as $\left|W_{n}^{X}(s)\right|^{2}$. The background power spectrum $\left(P_{k}\right)$ is defined as:

$$
P_{k}=\frac{\left(1-\alpha^{2}\right)}{\left|1-\alpha e^{-2 i \pi k}\right|^{2}}
$$

where $k$ is the Fourier frequency index, $\alpha$ is the correlation coefficient of autoregressive equation in power spectrum of red noise.

\subsection{The Cross Wavelet Transforms (XWT)}

The XWT mainly studies the multi-time scale correlation between two time series in time domain and frequency domain. This method can reveal the consistency and correlation of two series in different time scale, and reflect the phase relationship of two series in time-frequency space [23].

The XWT is built on two CWTs. The XWT of two time-series $x_{n}$ and $y_{n}$ is defined as $W^{X Y}=W^{X} W^{Y *}$, where $*$ represents complex conjugation. The cross-wavelet power further defined as $\left|W^{X Y}\right|$, if $\left|W^{X Y}\right|$ value is high, it indicates that the two have a common high-energy region, and they are significantly correlated with each other. The complex argument $\arg \left(W^{X Y}\right)$ can be interpreted as the local relative phase between $x_{n}$ and $y_{n}$ in time-frequency space. The theoretical distribution of the cross wavelet power of two time-series with background power spectra $P_{k}^{X}$ and $P_{k}^{Y}$ is defined as:

$$
D\left(\frac{\left|W_{n}^{X}(s) W_{n}^{Y *}(s)\right|}{\sigma_{X} \sigma_{Y}}<p\right)=\frac{Z_{v}(p)}{v} \sqrt{P_{k}^{X} P_{k}^{Y}}
$$

where $v$ is equal to 1 for real and 2 for complex wavelets, $Z_{v}(p)$ is the confidence level associated with the probability $p$ for a pdf (probability density function) defined by the square root of the product of two $\chi^{2}$ distributions.

\subsection{Cross Wavelet Phase Angle}

In order to know the phase difference between the components of the two time-series, it is necessary to estimate the mean and confidence interval of the phase difference. The circular mean of the phase over regions with higher than $5 \%$ statistical significance that are outside the COI (Cone of Influence, in which edge effects cannot be ignored) can be used to quantify the phase relationship. The circular mean of a set of angles $\left(\alpha_{i}, I=1, \ldots, n\right)$ is defined as:

$$
\alpha_{m}=\arg (X, Y)=\arg \left[\sum_{i=1}^{n} \cos \left(\alpha_{i}\right), \sum_{i=1}^{n} \sin \left(\alpha_{i}\right)\right]
$$

\subsection{Pearson Correlation Coefficient Method}

Pearson correlation coefficient is widely used to measure the linear relationship between two variables $x$ and $y$. Pearson correlation coefficient is defined as the quotient of covariance and standard deviation between two variables:

$$
r=\frac{\sum_{i=1}^{n}\left(x_{i}-\bar{x}\right)\left(y_{i}-\bar{y}\right)}{\sqrt{\sum_{i=1}^{n}\left(x_{i}-\bar{x}\right)^{2}} \sqrt{\sum_{i=1}^{n}\left(y_{i}-\bar{y}\right)^{2}}}
$$


In general, the larger the absolute value of the correlation coefficient between the two variables, the higher the degree of correlation between the two variables.

\section{Results}

\subsection{The XWT of Spring Water Level and Precipitation}

The XWT was used to analyze the relation between precipitation and spring water level. The XWT of precipitation and spring water level are shown in Figures 4 and 5. The first time-series is precipitation and the second time-series is spring water level. As shown in Figures 4 and 5, there is significant common power can be found with periodicity of one year from 2010 to 2019. Figures 4 and 5 are similar, because BTS and HHS are very close to each other (Figure 3), and the spring water level dynamics of the two springs are similar. In addition, the characteristics of annual distribution of precipitation is the same in different regions, i.e., over seventy percent of precipitation is concentrated between June and September [2]. The XWT phase angle within the 5\% significant regions, outside the COI and with a period between 0.95 and 1.05 years was calculated. The time-lag of precipitation and spring water level was quantitatively analyzed through the cross wavelet phase angle.

Table 2 displays the outcomes of the calculations. For example, the XWT phase angle of precipitation of Xinglong station and BTS water level within the $5 \%$ significant regions and outside the COI has the mean phase $1.61 \pm 0.07 \mathrm{rad}$. The value before " \pm " is the average XWT phase angle, and the value after " \pm " is the circular standard deviation. The XWT phase angle can be used to calculate time-lag. Because the spring water level varies after the precipitation changes, the average phase angles are all positive, and the circular standard deviation has no effect on the phase angle. Since the cross phase $2 \pi \mathrm{rad}$ corresponds to a period of one year, the time-lag was calculated, which falls within the range of 3 to 4 months.

Table 2. Cross-wavelet phases and time intervals of precipitation and spring water level.

\begin{tabular}{cccccc}
\hline & \multicolumn{2}{c}{ BTS } & \multicolumn{2}{c}{ HHS } & Rank \\
\cline { 2 - 5 } Station & $\begin{array}{c}\text { Phase Angle } \\
\text { (Rad) }\end{array}$ & $\begin{array}{c}\text { Mean Time-Lag } \\
\text { (Day) }\end{array}$ & $\begin{array}{c}\text { Phase Angle } \\
\text { (Rad) }\end{array}$ & $\begin{array}{c}\text { Mean Time-Lag } \\
\text { (Day) }\end{array}$ & \\
\hline Xinglong & $1.61 \pm 0.07$ & $93.81 \pm 4.03$ & $1.61 \pm 0.08$ & $93.79 \pm 4.84$ & 1 \\
Donghongmiao & $1.62 \pm 0.10$ & $94.39 \pm 5.97$ & $1.62 \pm 0.11$ & $94.37 \pm 6.63$ & 2 \\
Qiujiazhuang & $1.63 \pm 0.10$ & $94.49 \pm 6.01$ & $1.63 \pm 0.12$ & $94.46 \pm 6.71$ & 3 \\
Xiying & $1.63 \pm 0.10$ & $94.61 \pm 5.8$ & $1.63 \pm 0.11$ & $94.59 \pm 6.41$ & 4 \\
Yanzishan & $1.64 \pm 0.07$ & $95.11 \pm 4.23$ & $1.64 \pm 0.09$ & $95.08 \pm 5.09$ & 5 \\
Liubu & $1.64 \pm 0.09$ & $95.26 \pm 5.24$ & $1.64 \pm 0.10$ & $95.24 \pm 5.72$ & 6 \\
Jijiayu & $1.65 \pm 0.10$ & $95.80 \pm 5.97$ & $1.65 \pm 0.12$ & $95.78 \pm 6.97$ & 7 \\
Shaoer & $1.69 \pm 0.10$ & $98.20 \pm 5.67$ & $1.69 \pm 0.11$ & $98.17 \pm 6.50$ & 8 \\
Gushan & $1.70 \pm 0.08$ & $98.54 \pm 4.48$ & $1.70 \pm 0.09$ & $98.52 \pm 4.94$ & 9 \\
Wohushan & $1.72 \pm 0.08$ & $99.7 \pm 4.86$ & $1.72 \pm 0.09$ & $99.68 \pm 5.45$ & 10 \\
Wande & $1.74 \pm 0.07$ & $101.2 \pm 3.89$ & $1.74 \pm 0.06$ & $101.18 \pm 3.75$ & 11 \\
Wopu & $1.74 \pm 0.07$ & $101.28 \pm 4.00$ & $1.74 \pm 0.07$ & $101.25 \pm 4.06$ & 12 \\
Changqing & $1.75 \pm 0.10$ & $101.38 \pm 5.58$ & $1.74 \pm 0.10$ & $101.36 \pm 5.77$ & 13 \\
Nangaoer & $1.75 \pm 0.08$ & $101.55 \pm 4.41$ & $1.75 \pm 0.08$ & $101.53 \pm 4.69$ & 14 \\
Huangtaiqiao & $1.79 \pm 0.07$ & $103.76 \pm 4.34$ & $1.79 \pm 0.09$ & $103.73 \pm 4.97$ & 15 \\
\hline
\end{tabular}

The time-lag of BTS water level to precipitation is around 93.81-103.76 days while the time-lag of HHS water level to precipitation is around 93.79-103.73 days. The Pearson correlation coefficient of time-lag and distance from springs to precipitation stations was calculated; the correlation coefficients of BTS and HHS were -0.2956 and -0.3025 , respectively, indicating that the farther the precipitation station location is, the longer the time-lag. However, the absolute value of the correlation coefficient is not large, the relationship between distance and time-lag is faint, illustrating that the distance has a limited impact on the time-lag, so the time-lag is mainly affected by other factors such as the hydrogeological conditions of the position of precipitation station. 


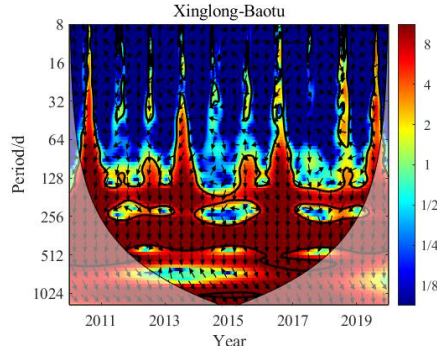

(a)

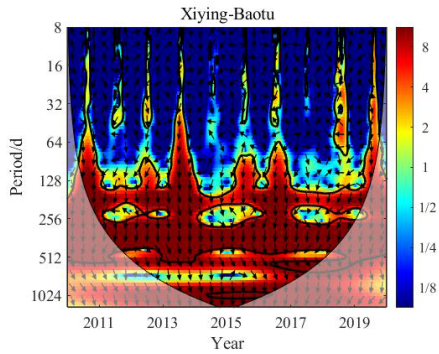

(d)

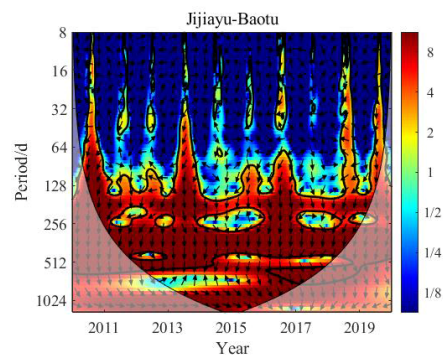

(g)

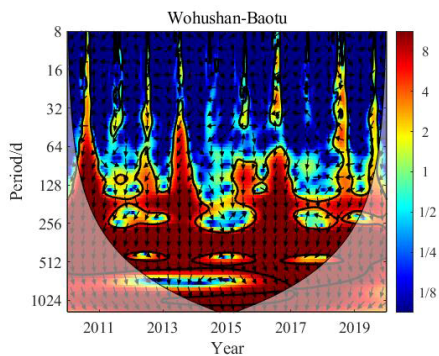

(j)

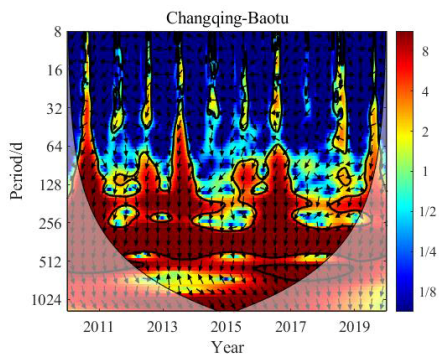

(m)

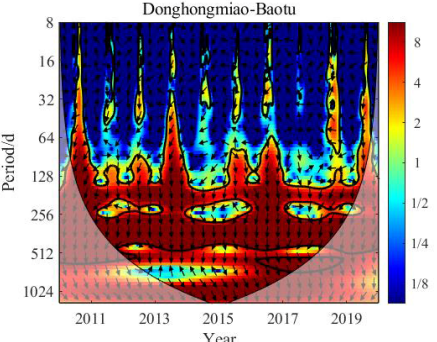

(b)

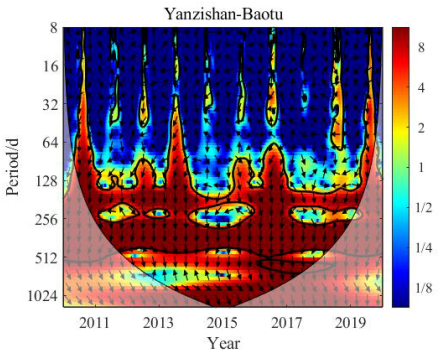

(e)

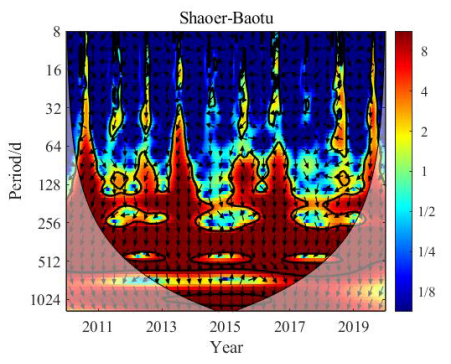

(h)

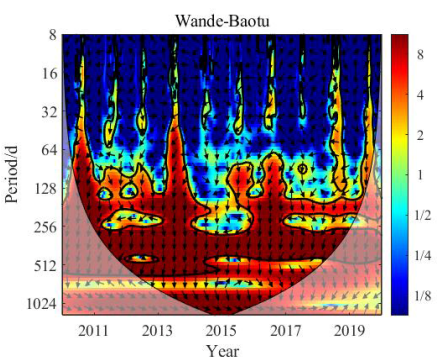

(k)

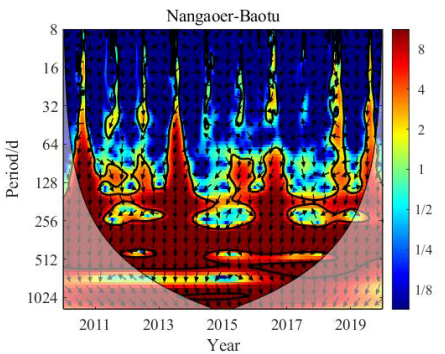

(n)

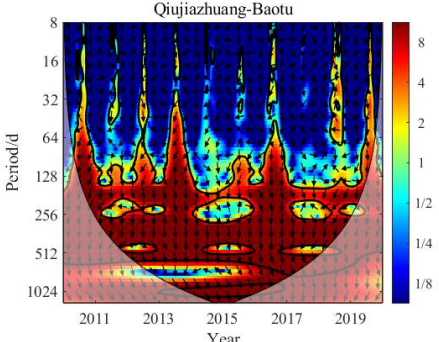

(c)

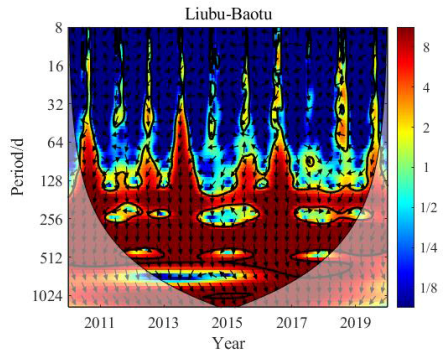

(f)

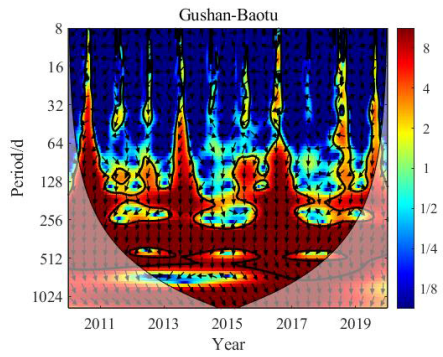

(i)

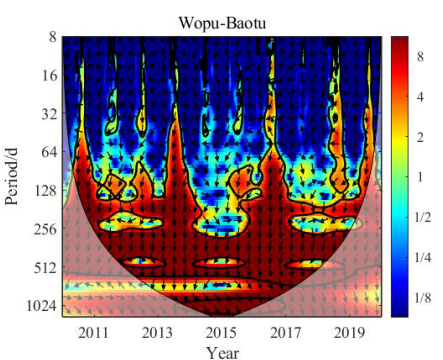

(1)

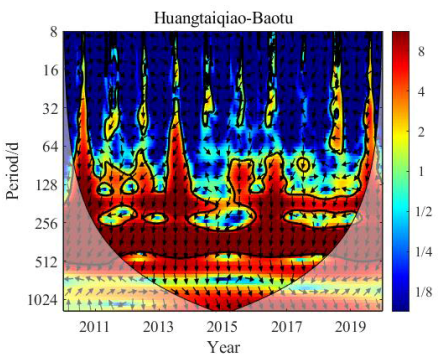

(o)

Figure 4. The XWTs of precipitation and BTS water level. (a-o) fifteen precipitation stations. The color scale indicates the cross wavelet power spectrum density corresponding to the different colors. The red and blue on the color scale represent the peak and valley values of power spectrum density, respectively. The thick black contour designates the $5 \%$ significance level against red noise, lighter shade represents the COI, and the arrows represents relative phase relationship of two time-series. The relative phase relationship of the two time-series is shown as arrows (with in-phase pointing right, anti-phase pointing left [13].) 


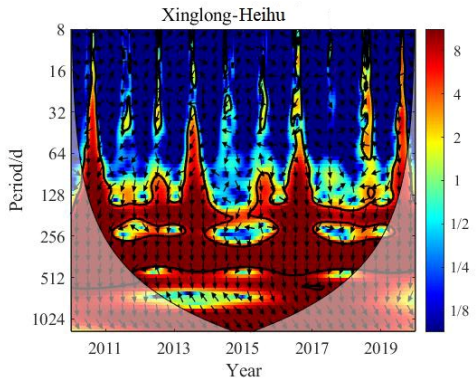

(a)

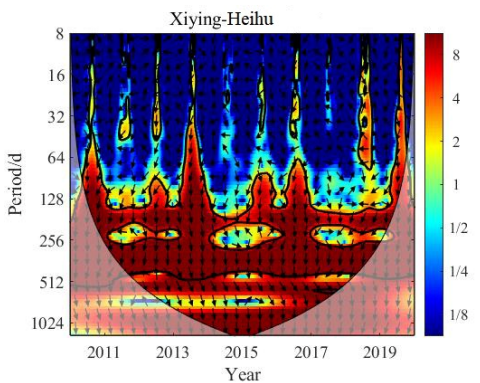

(d)

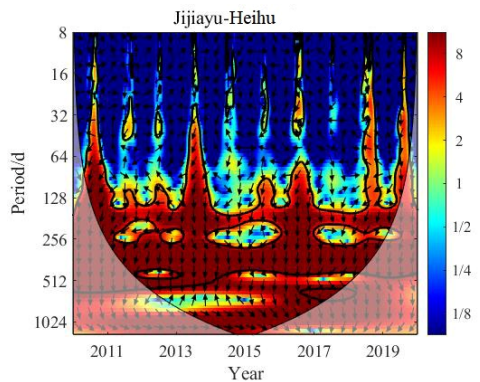

(g)

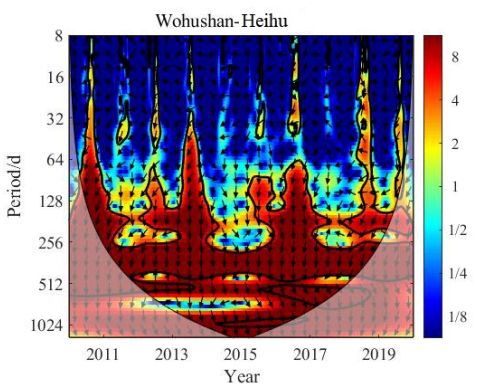

(j)

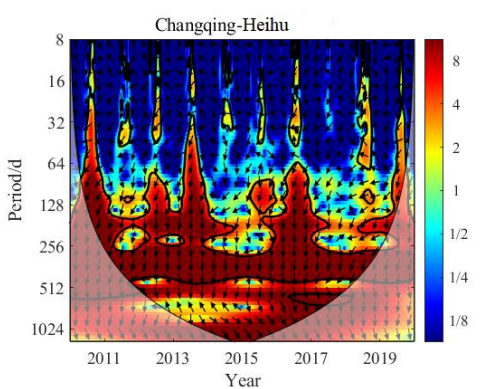

(m)

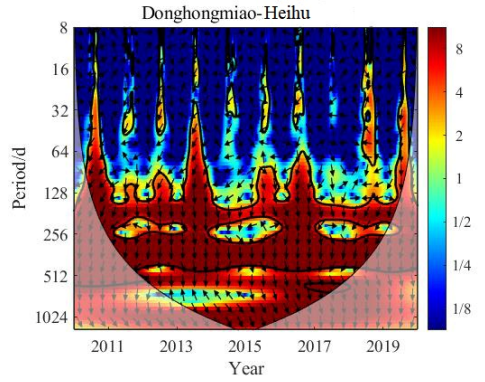

(b)

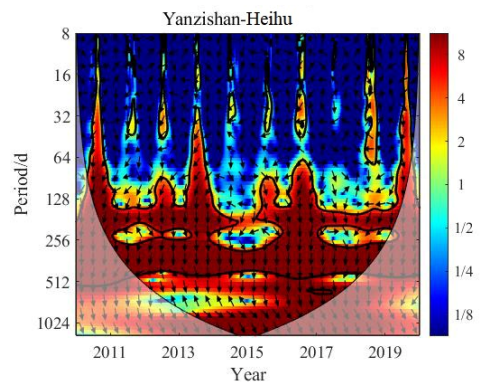

(e)

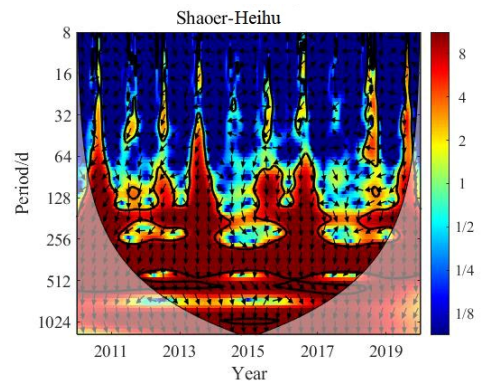

(h)

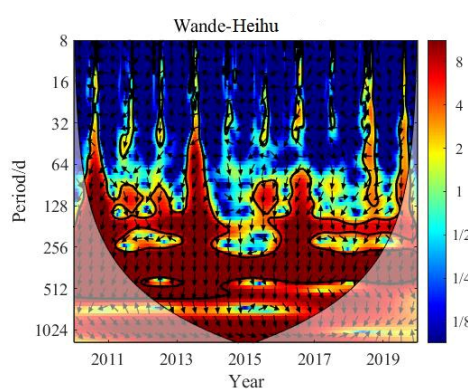

(k)

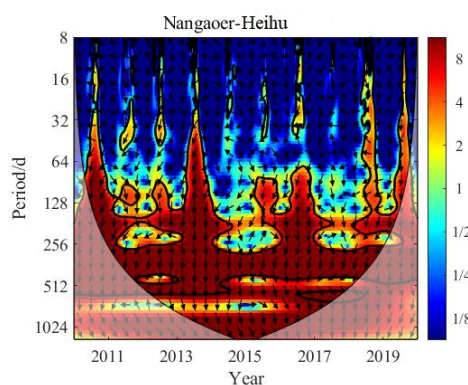

(n)

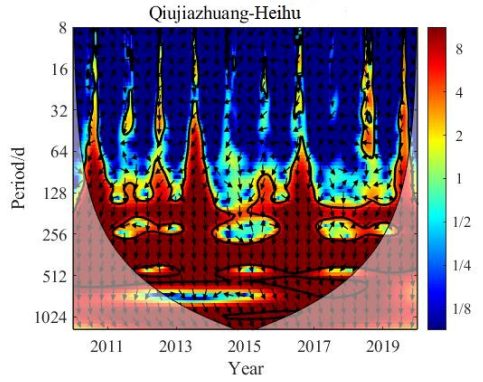

(c)

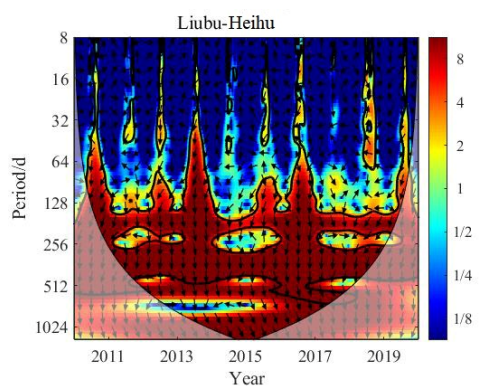

(f)

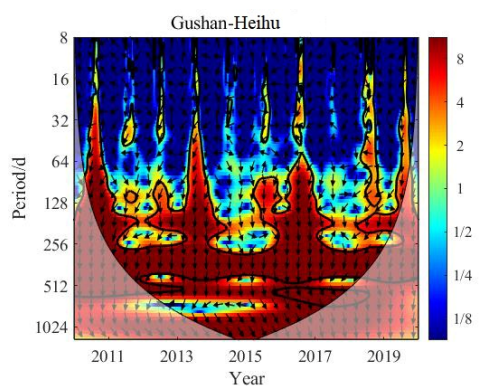

(i)

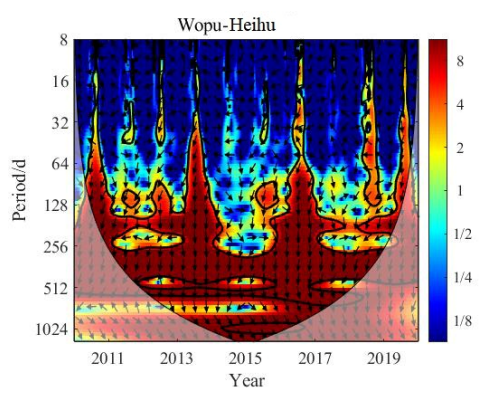

(1)

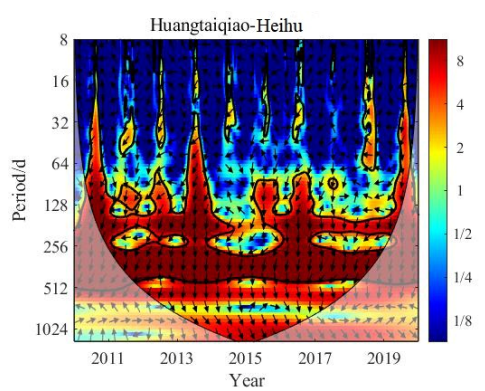

(o)

Figure 5. The XWTs of precipitation and HHS water level. (a-o) fifteen precipitation stations. 
The XWT was applied to quantitatively evaluate the time-lag between spring water level and precipitation, and the time-lag of the two was compared and ranked. The result showed that Xinglong, Donghongmiao, Qiujiazhuang, Xiying, Yanzishan, Liubu stations are most likely to be located on the preferential runoff belts.

\subsection{Pearson Correlation Coefficient of Spring Water Level and Precipitation}

The Pearson correlation coefficient of monthly precipitation and spring water levels of BTS and HHS was calculated and ranked (Table 3), the correlation coefficients are small, but a high correlation might not always mean that there is a good relationship between the variables and a correlation close to zero might not mean that there is no relationship between the variables. This approach, without considering the variation of behavior seen through time series data, might cause misleading results [32,38].

Table 3. Correlation coefficient of spring water level and precipitation.

\begin{tabular}{cccc}
\hline Station & BTS & HHS & Rank \\
\hline Xinglong & 0.1687 & 0.1566 & 1 \\
Donghongmiao & 0.1626 & 0.1507 & 2 \\
Qiujiazhuang & 0.1604 & 0.1478 & 3 \\
Xiying & 0.1467 & 0.1342 & 4 \\
Yanzishan & 0.1463 & 0.1333 & 5 \\
Liubu & 0.1454 & 0.1326 & 6 \\
Jijiayu & 0.1380 & 0.1241 & 7 \\
Shaoer & 0.1284 & 0.1154 & 8 \\
Gushan & 0.1283 & 0.1154 & 9 \\
Wohushan & 0.1268 & 0.1145 & 10 \\
Wande & 0.1235 & 0.1089 & 11 \\
Wopu & 0.1142 & 0.0996 & 13 \\
Changqing & 0.1139 & 0.0978 & 14 \\
Nangaoer & 0.1065 & 0.0928 & 15 \\
Huangtaiqiao & 0.1025 & 0.0878 & \\
\hline
\end{tabular}

According to Figure 3 and the previous result, the variation of spring water level lags behind precipitation. If the spring has no response time to precipitation, the correlation coefficient will be relatively large, and the correlation coefficient is about 0.3-0.4. However, there is a time-lag of 3-4 months between precipitation and spring water level, and the time-lag will affect the correlation coefficient between the two, so the correlation coefficient is small. The effect of the distance from BTS and HHS to precipitation stations on the results was analyzed; the Pearson correlation coefficient of BTS and HHS were -0.3313 and -0.3483 , respectively, indicating that the farther the precipitation station location is, the smaller the correlation coefficient. The stations with the largest correlation coefficients are: Xinglong, Xiying, Yanzishan, Donghongmiao, Qiujiazhuang, and Liubu stations. These stations are same as the results obtained by the XWT.

\subsection{The XWT and Correlation Coefficient of Groundwater Level and Precipitation}

Because karst groundwater in the Jinan Spring Basin mainly flows from south to north, while observation wells S46 and S86 are located in the northwest of the Jinan Spring Basin (Figure 1), and these two observation wells have the same time-series data with precipitation. The XWT and Pearson correlation coefficient were used to assess the relationship between precipitation and groundwater level; the results also reveal that Xinglong, Xiying, Yanzishan, Donghongmiao, Qiujiazhuang, and Liubu stations are more likely to be on the preferential runoff belts. The result of the above six stations are shown in Table 4 and Figure 6, but the time-lag of precipitation and groundwater level is longer than that of precipitation and spring water level; the correlation coefficient of precipitation and groundwater level is obviously smaller than that of the precipitation and spring water 
level. This shows that precipitation and spring water level are more correlated, and that precipitation is more likely to affect springs in the northeast.

Table 4. Time-lag and Correlation coefficient of groundwater level and precipitation.

\begin{tabular}{ccccc}
\hline \multirow{2}{*}{ Station } & \multicolumn{2}{c}{ Mean Time-Lag } & \multicolumn{2}{c}{ Correlation Coefficient } \\
\cline { 2 - 5 } & S46 & S86 & S46 & S86 \\
\hline Xinglong & $102.05 \pm 5.80$ & $112.87 \pm 5.80$ & 0.0659 & 0.0435 \\
Donghongmiao & $101.66 \pm 7.04$ & $112.47 \pm 6.63$ & 0.0526 & 0.0231 \\
Qiujiazhuang & $101.71 \pm 6.85$ & $112.51 \pm 6.69$ & 0.0382 & 0.0431 \\
Xiying & $101.97 \pm 7.34$ & $112.78 \pm 6.33$ & 0.0537 & 0.0274 \\
Yanzishan & $103.22 \pm 5.62$ & $114.03 \pm 5.98$ & 0.0982 & 0.0326 \\
Liubu & $102.80 \pm 7.05$ & $113.62 \pm 5.64$ & 0.0584 & 0.0031 \\
\hline
\end{tabular}

\subsection{Verification Based on Hydrogeological Conditions of Study Area}

In karst areas, precipitation infiltration recharges groundwater, which causes groundwater level to rise, and hydraulic pressure to propagate through the aquifer. Spring is natural outcrop of groundwater; as the pressure waves reach the spring outlet, the groundwater is forced to surface, altering the spring water level. The spring water level variance is the response of groundwater aquifer system to precipitation. The direction and intensity of karst groundwater runoff are influenced by topography, lithology and geological structure in the study area. In the Jinan Spring Basin, the overall direction of karst groundwater runoff is from southeast to northwest. The Qianfoshan Fault plays an important role in groundwater runoff, and the northern part of it is permeable $[39,40]$. The northern area of the Qianfoshan Fault has good permeability $[9,15,41]$, and the fractures and conduits near the fault are relatively developed. The hydrogeological conditions for the location of each precipitation station were analyzed individually. Yanzishan Station is located in an area with Ordovician limestone aquifer and has a short straight-line distance to spring. Considering the overall flow direction of groundwater in the Jinan Spring Basin, the precipitation at Yanzishan station recharges spring along the direction of groundwater runoff. Existing hydrogeological data showed that when groundwater reaches the north of the Jinan Spring Basin, the groundwater runoff will be blocked by the northern impermeable magmatic rock, which will divert groundwater runoff to the east. Because the fissures in the northern part of the Qianfoshan Fault are extremely well developed and the permeability is high, groundwater runoff can recharge the springs through the northern part of the Qianfoshan Fault, so the precipitation of Donghongmiao station can easily recharge groundwater, and groundwater runoff recharge the spring through the Qianfoshan Fault. Hence, Donghongmiao station also has the likelihood of being located on a preferential runoff belt. Liubu, Qiujiazhuang and Xinglong Stations are distributed along the Qianfoshan Fault, and the direction of groundwater runoff is controlled by the impermeable part of the Qianfoshan Fault, and precipitation can recharge spring along the Qianfoshan Fault, and both Qiujiazhuang and Liubu stations are located in the area near the fault and with strong karst development. The Xiying station is situated in the east side of the Qianfoshan Fault. In addition, the aquifer at the Xiying station is the Cambrian Zhangxia Formation. According to previous drilling data, the Zhangxia Formation is basically composed of thick oolitic limestone with the highest degree of karst development, the water-bearing formation is highly soluble and has strong karst development, so groundwater runoff along the water-rich zone to the northwest, and then recharge spring along the Qianfoshan Fault.

According to the hydrogeological conditions of each precipitation station, Xinglong, Donghongmiao, Qiujiazhuang, Xiying, Yanzishan, and Liubu stations all meet the characteristics of being located on the preferential runoff belts. The runoff belts in the Jinan Spring Basin are the Liubu-Qiujiazhuang-Xinglong belt along the Qianfoshan Fault, the Xiying-Yanzishan belt on the west side of the Qianfoshan Fault, and the Donghongmiaonorthern part of the Qianfoshan Fault-Baotu Spring belt. The preferential runoff belts are marked in the water-abundance zone map of the Jinan Spring Basin, as shown in Figure 7. 
The location of preferential runoff belts provides a primary field for spring recharge and water supply.

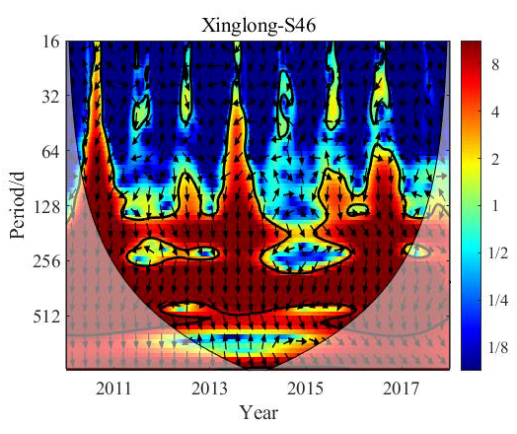

(a)

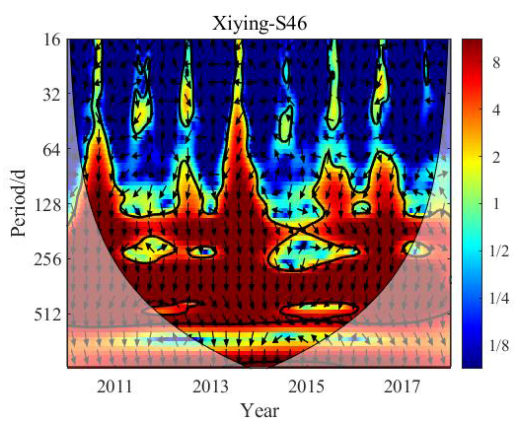

(d)

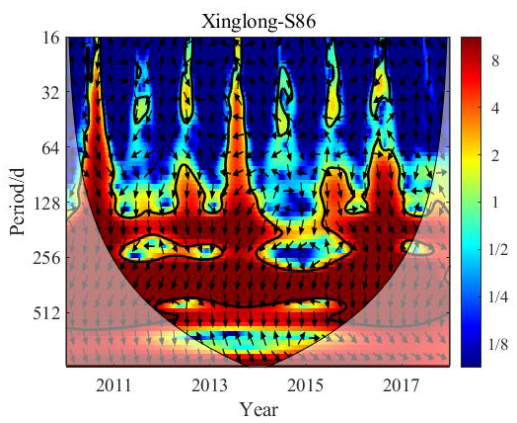

(g)

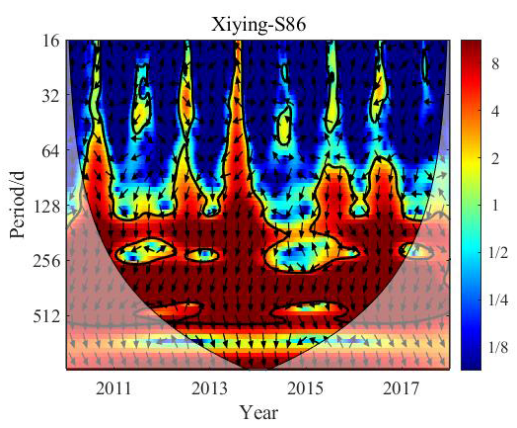

(j)

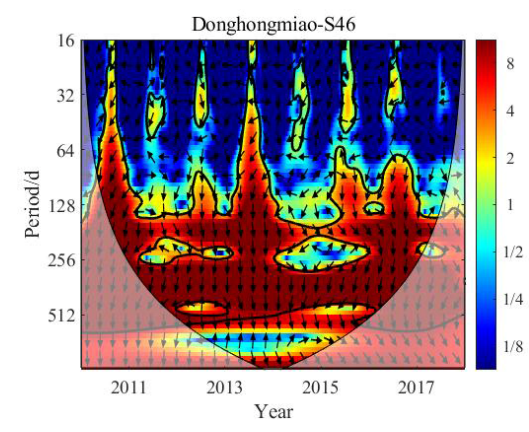

(b)

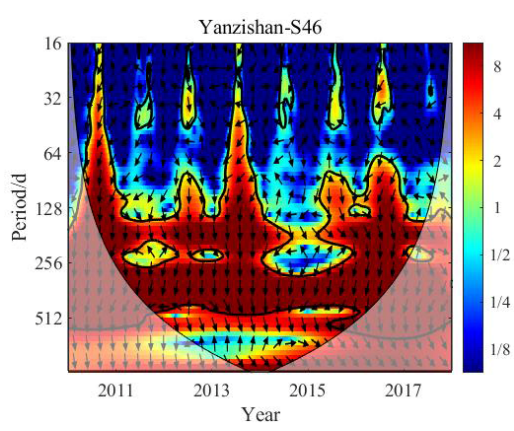

(e)

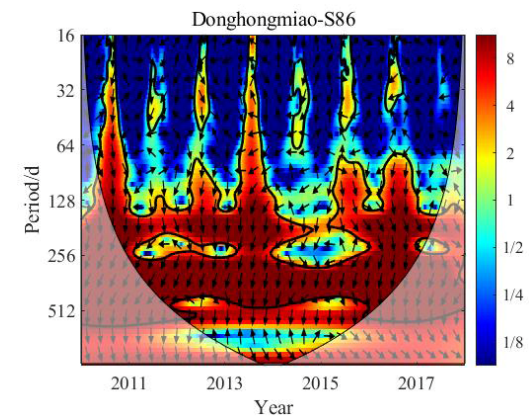

(h)

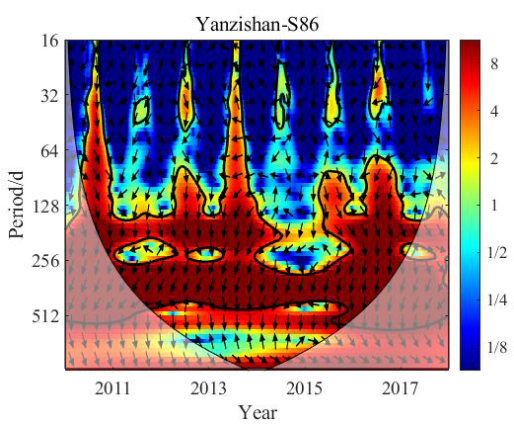

$(\mathbf{k})$

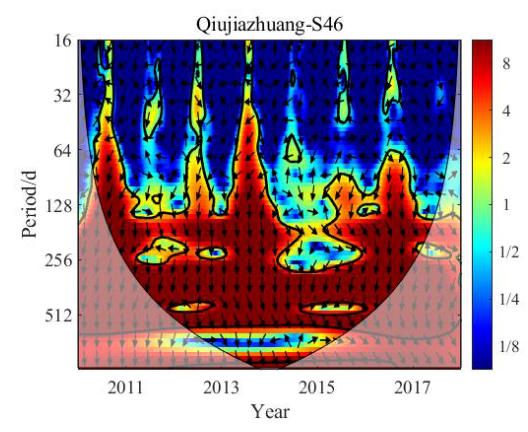

(c)

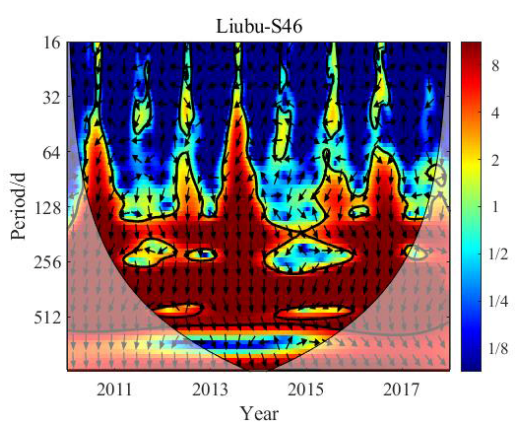

(f)

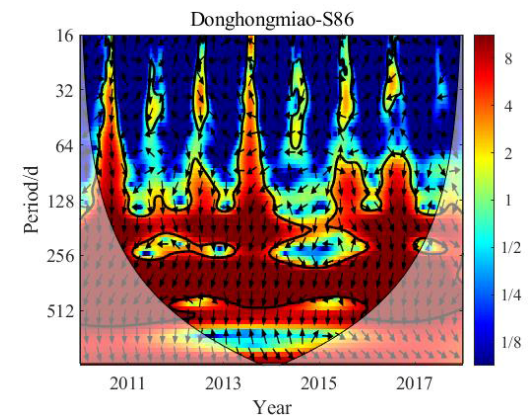

(i)

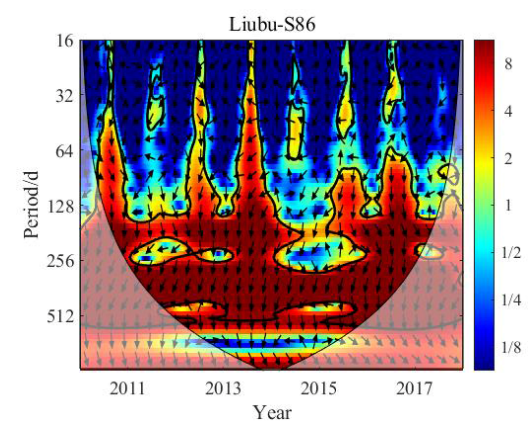

(1)

Figure 6. The XWTs of precipitation and groundwater level. (a-f) six precipitation stations and S46; (g-1) six precipitation stations and S86. 


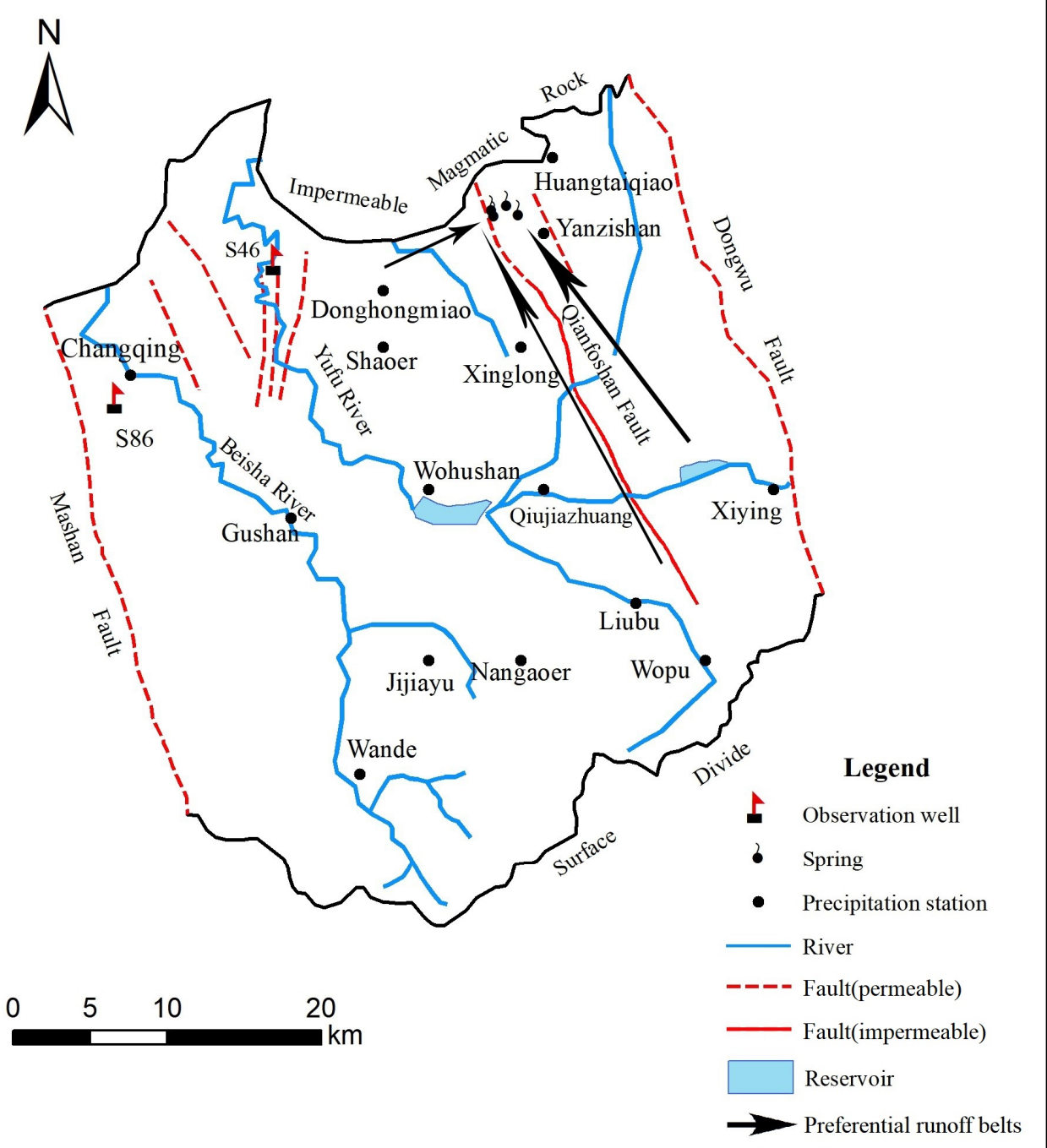

Figure 7. Location of preferential runoff belts in Jinan Spring Basin.

\section{Conclusions}

The time-lag and correlation of spring water level and precipitation time series were computed using mathematical statistics methods, in conjunction with the hydrogeological characteristics of the Jinan Spring Basin. The following conclusions were drawn:

(1) The time-lag of BTS and HHS water level and precipitation within the range is 3-4 months. The results of XWT and Pearson correlation coefficient indicated that Xinglong, Donghongmiao, Qiujiazhuang, Xiying, Yanzishan, and Liubu stations are more likely to be located on preferential runoff belt.

(2) Based on the hydrogeological conditions of the Jinan Spring Basin, the approximate location of the preferential runoff belt was identified: the Liubu-Qiujiazhuang-Xinglong belt along the Qianfoshan Fault, the Xiying-Yanzishan belt on the west side of the Qianfoshan Fault, and the Donghongmiao- northern part of the Qianfoshan FaultBTS belt.

(3) The time-lag and correlation between groundwater level and precipitation in the Jinan Spring Basin are still not clear, the mechanism of the quick response of groundwater level to precipitation is still obscure. Further study is necessary to use more appropriate mathematical methods and more hydrological time-series data to identify the location of preferential runoff belt, and to conduct more fundamental theory research on this subject. 
Author Contributions: L.S. and S.N. conceived and designed this study; S.N. analyzed the data; H.X. provided data and information for this study; H.L. and X.W. provided funding support; Y.L. and P.A.O. participated in the revision. All authors have read and agreed to the published version of the manuscript.

Funding: This research was funded by the Major Innovation and Technology Projects of Shandong Province (No. 2019JZZY020105).

Institutional Review Board Statement: Not applicable.

Informed Consent Statement: Not applicable.

Data Availability Statement: The relevant data is available on the request to the corresponding author.

Acknowledgments: All authors are very grateful to the editor and the anonymous reviewers for their valuable comments.

Conflicts of Interest: The authors declare no conflict of interest.

\section{References}

1. Duran, L.; Massei, N.; Lecoq, N.; Fournier, M.; Labat, D. Analyzing multi-scale hydrodynamic processes in karst with a coupled conceptual modeling and signal decomposition approach. J. Hydrol. 2020, 583, 124625. [CrossRef]

2. Zhang, Z.X.; Wang, W.P.; Qu, S.S.; Huang, Q.; Liu, S.; Xu, Q.Y.; Ni, L.D. A New Perspective to Explore the Hydraulic Connectivity of Karst Aquifer System in Jinan Spring Catchment, China. Water 2018, 10, 1368. [CrossRef]

3. Zhu, H.H.; Xing, L.T.; Meng, Q.H.; Xing, X.R.; Peng, Y.M.; Li, C.S.; Li, H.; Yang, L.Z. Water Recharge of Jinan Karst Springs, Shandong, China. Water 2020, 12, 694. [CrossRef]

4. Qian, J.Z.; Zhan, H.B.; Wu, Y.F.; Li, F.L.; Wang, J.Q. Fractured-karst spring-flow protections: A case study in Jinan, China. Hydrogeol. J. 2006, 14, 1192-1205. [CrossRef]

5. Yu, M.; Xing, L.T.; Wu, J.C.; Hou, Y.S.; Zhu, H.H.; Peng, Y.M.; Li, G. Study of large karst springs using the time series fractal method in Jinan. Actag Eologica Sin. 2020, 94, 2509. (In Chinese)

6. Zhou, J.; Xing, L.T.; Teng, Z.X.; Wang, L.Y. Study on the threshold of main factors restricting Jinan large karst springs spewing. J. East China Norm. Univ. (Nat. Sci.) 2015, 2015, 146-156. (In Chinese)

7. Wang, M.M.; Shu, L.C.; Ji, Y.F.; Tao, Y.F.; Dong, G.M.; Liu, L.H. Causes of spring's of flux attenuation and simulation of spring's regime-A case in Jinan karst spring area. Carsologica Sin. 2008, 27, 19-23. (In Chinese)

8. Xing, L.T.; Huang, L.X.; Chi, G.Y.; Yang, L.Z.; Li, C.S.; Hou, X.Y. A Dynamic Study of a Karst Spring Based on Wavelet Analysis and the Mann-Kendall Trend Test. Water 2018, 10, 698. [CrossRef]

9. Ni, H.X.; Shu, L.C.; Han, G.; Zhang, M.Q.; Wang, X.; Wang, X.B.; Yu, Y.F.; Opoku, P.A. Impact of urbanization on precipitation infiltration recharge in Jinan Spring Basin. S.-N. Water Transf. Water Sci. Technol. 2020, 18, 64-70. (In Chinese)

10. Qi, X.F.; Wang, Y.S.; Yang, L.Z.; Liu, Z.Y.; Li, W.P. Time lag variance of groundwater level response to precipitation of Jinan karst spring watershed in recent 50 years. Carsol. Sin. 2016, 35, 384-393. (In Chinese)

11. An, L.X.; Ren, X.Y.; Hao, Y.H.; Yen, T.Q.; Zhang, B.J. Utilizing Precipitation and Spring Discharge Data to Identify Groundwater Quick Flow Belts in a Karst Spring Catchment. J. Hydrometeorol. 2019, 20, 2057-2068. [CrossRef]

12. Francesco, F.; Francesco, M.G. Karst Spring Discharges Analysis in Relation to Drought Periods, Using the SPI. Water Resour. Manag. 2010, 24, 1867-1884.

13. Pardo Igúzquiza, E.; Dowd, P.A.; Xu, C.S.; Durán-Valsero, J.J. Stochastic simulation of karst conduit networks. Adv. Water Resour. 2012, 35, 141-150. [CrossRef]

14. Atkinson, T.C. Diffuse flow and conduit flow in limestone terrain in Mendip Hills, Somerset (Great Britain). J. Hydrol. 1977, 35, 100. [CrossRef]

15. Xing, L.T.; Li, C.S.; Zhou, J.; Song, G.Z.; Xing, X.R. The Characteristics of Karst Channel in the Spring of Ji'nan Spring Region. Sci. Technol. Eng. 2017, 17, 57-65. (In Chinese)

16. Zhu, H.X.; Xing, L.T.; Xiang, H.; Chi, G.Y.; Hou, X.Y. Application of tracer test in the study of preferential runoff path of Ji'nan spring group. Ground Water 2017, 39, 5-7. (In Chinese)

17. Hartmann, A.; Goldscheider, N.; Wagener, T.; Lange, J.; Weiler, M. Karst water resources in a changing world: Review of hydrological modeling approaches. Rev. Geophys. 2014, 52, 218-242. [CrossRef]

18. Hu, C.H.; Hao, Y.H.; Yeh, T.C.J.; Pang, B.; Wu, Z.N. Simulation of spring flows from a karst aquifer with an artificial neural network. Hydrol. Process. 2008, 22, 596-604. [CrossRef]

19. Labat, D.; Ababou, R.; Mangin, A. Rainfall-runoff relations for karstic springs. Part I: Convolution and spectral analyses. J. Hydrol. 2000, 238, 123-148. [CrossRef]

20. Labat, D. Cross wavelet analyses of annual continental freshwater discharge and selected climate indices. J. Hydrol. 2010, 385, 269-278. [CrossRef]

21. Labat, D. Wavelet analysis of the annual discharge records of the world's largest rivers. Adv. Water Resour. 2008, 31, 109-117. [CrossRef] 
22. Szolgayova, E.; Parajka, J.; Bloschl, G.; Bucher, C. Long term variability of the Danube River flow and its relation to precipitation and air temperature. J. Hydrol. 2014, 519, 871-880. [CrossRef]

23. Rashid, M.M.; Beecham, S.; Chowdhury, R.K. Assessment of trends in point rainfall using Continuous Wavelet Transforms. Adv. Water Resour. 2015, 82, 1-15. [CrossRef]

24. Grinsted, A.; Moore, J.C.; Jevrejeva, S. Application of the cross wavelet transform and wavelet coherence to geophysical time series. Nonlinear Proc. Geoph. 2004, 11, 561-566. [CrossRef]

25. Wu, C.C.; Zhang, X.Q.; Wang, W.J.; Lu, C.P.; Zhang, Y.; Qin, W.; Tick, G.R.; Liu, B.; Shu, L.C. Groundwater level modeling framework by combining the wavelet transform with a long short-term memory data-driven model. Sci. Total Environ. 2021, 783, 146948. [CrossRef]

26. Lin, Y.; Qu, P.C.; Lv, H.X.; Wu, Y.Z. Variation characteristics of typical karst springs in the eastern margin of the Taihang Mountains. Carsologica Sin. 2018, 37, 671-679. (In Chinese)

27. Miao, J.J.; Liu, G.L.; Cao, B.B.; Hao, Y.H.; Yen, T.Q. Identification of Strong Karst Groundwater Runoff Belt by Cross Wavelet Transform. Water Resour. Manag. 2014, 28, 2903-2916. [CrossRef]

28. Qi, X.F.; Li, W.P.; Li, H.T.; Yang, L.Z. Teleconnections between groundwater levels, precipitation, air temperature of the Jinan karst springs watershed and large scale climatic patterns. Hydrogeol. Eng. Geol. 2015, 42, 18-28. (In Chinese)

29. Wan, L.; Zhang, X.P.; Ma, Q.; Zhang, J.J.; Ma, T.Y.; Sun, Y.P. Spatiotemporal characteristics of precipitation and extreme events on the Loess Plateau of China between 1957, and 2009. Hydrol. Process 2014, 28, 4971-4983. [CrossRef]

30. Tabari, H.; Kisi, O.; Ezani, A.; Talaee, P.H. SVM, ANFIS, regression and climate based models for reference evapotranspiration modelling using limited climatic data in a semi-arid highland environment. J. Hydrol. 2012, 444-445, 78-89. [CrossRef]

31. Bai, Y.; Bezak, N.; Zeng, B.; Li, C.; Sapac, K.; Zhang, J. Daily Runoff Forecasting Using a Cascade Long Short-Term Memory Model that Considers Different Variables. Water Resour. Manag. 2021, 35, 1167-1181. [CrossRef]

32. Dikbaş, F. A novel two-dimensional correlation coefficient for assessing associations in time series data. Int. J. Climatol. 2017, 37, 4065-4076. [CrossRef]

33. Wang, J.J.; Xu, Z.X.; Li, P.; Cheng, T.; Su, H. Characteristics and attribution of groundwater depth changes in Jinan City. S.-N. Water Transf. Water Sci. Technol. 2021, 19, 883-893. (In Chinese)

34. Seung, H.L.; Chang, W.O.; Jung, W.P. The age and geochemistry of the mid-Cretaceous volcanic rocks in the Jinan Basin: Implications for the mid-Cretaceous tectonic environments of the Korean Peninsula and Northeast Asia. Lithos 2020, 358-359, 105383.

35. Guo, Y.; Qin, D.J.; Li, L.; Sun, J.; Li, F.L.; Huang, J.W. A Complicated Karst Spring System: Identified by Karst Springs Using Water Level, Hydrogeochemical, and Isotopic Data in Jinan, China. Water 2019, 11, 947. [CrossRef]

36. Wang, J.L.; Jin, M.G.; Lu, G.P.; Zhang, D.L.; Kang, F.X.; Jia, B.J. Investigation of discharge-area groundwaters for recharge source characterization on different scales: The case of Jinan in northern China. Hydrogeol. J. 2016, 24, 1723-1737. [CrossRef]

37. Kang, F.X.; Jin, M.G.; Qin, P.R. Sustainable yield of a karst aquifer system: A case study of Jinan springs in northern China. Hydrogeol. J. 2011, 19, 851-863. [CrossRef]

38. Brett, M.T. When is a correlation between non-independent variables "spurious"? Oikos 2004, 105, 647-656. [CrossRef]

39. Zhang, Z.X.; Liu, Y.; Zhang, F.X. Prediction of groundwater table based on time series models in Baotu Spring of Jinan. J. China Inst. Water Resour. Hydropower Res. 2019, 17, 51-59. (In Chinese)

40. Gao, Z.J.; Xu, J.X.; Wang, S.C.; Li, C.S.; Han, K.; Li, J.J.; Luo, F.; Ma, H.K. The distribution characteristics and hydrogeological significance of trace elements in karst water, Jinan, China. Earth Sci. Front. 2014, 21, 135-146. (In Chinese)

41. Hu, J.B.; Liang, H.F.; Li, G.L. Study on the characteristics of karst development in Jinan Spring Basin. China Steel Focus. 2020, 395, 134-150. (In Chinese) 